107 Royal Netherlands Institute for Sea Research

This is a postprint of:

Hummel, H., et al. (2015). A comparison of the degree of implementation of marine biodiversity indicators by European countries in relation to the Marine Strategy Framework Directive (MSFD). Journal of the Marine Biological Association of the United Kingdom, 95(8), 1519-1531

Published version: $\underline{\mathrm{dx} . \text { doi.org/10.1017/S0025315415000235 }}$

Link NIOZ Repository: www.vliz.be/nl/imis?module=ref\&refid=251984

[Article begins on next page]

The NIOZ Repository gives free access to the digital collection of the work of the Royal Netherlands Institute for Sea Research. This archive is managed according to the principles of the Open Access Movement, and the Open Archive Initiative. Each publication should be cited to its original source - please use the reference as presented.

When using parts of, or whole publications in your own work, permission from the author(s) or copyright holder(s) is always needed. 


\section{A comparison on the degree of implementation of marine biodiversity indicators by European countries in relation to the Marine Strategy Framework Directive (MSFD)}

Herman Hummel ${ }^{1 *}$, Matt Frost ${ }^{2}$, José A. Juanes ${ }^{3}$, Judith Kochmann ${ }^{4}$, Carlos F. Castellanos Perez Bolde $^{5}$, Fernando Aneiros ${ }^{6}$, François Vandenbosch ${ }^{7,8}$, João N. Franco ${ }^{9}$, Beatriz Echavarri ${ }^{3}$, Xabier Guinda ${ }^{3}$, Araceli Puente ${ }^{3}$, Camino Fernández $^{3}$, Cristina Galván $^{3}$, Maria Merino $^{3}$, Elvira Ramos ${ }^{3}$, Paloma Fernández ${ }^{3}$, Valentina Pitacco ${ }^{10}$, Madara Alberte ${ }^{11}$, Dagmara Wojcik ${ }^{12}$, Monika Orchowska ${ }^{13}$, Marlene Jahnke ${ }^{14}$, Fabio Crocetta ${ }^{14}$, Laura Carugati ${ }^{15}$, Simonetta Scorrano ${ }^{16}$, Simonetta Fraschetti ${ }^{16}$, Patricia Pérez García ${ }^{17}$, José Antonio Sanabria Fernández ${ }^{17,18}$, Artem Poromov $^{19}$, Anna lurchenko ${ }^{19}$, Artem Isachenko ${ }^{19}$, Alexandra Chava ${ }^{19}$, Christina Pavloudi $^{20}$, François Bordeyne ${ }^{7,8}$, Simone Fie Andersen ${ }^{21}$, Elizabeth Grace Tunka Eronat ${ }^{22}$, Taylan Cakmak ${ }^{23}$, Paraskevi Louizidou ${ }^{24}$, José Rico ${ }^{25}$, Stela Ruci ${ }^{26}$, David Corta Diego ${ }^{27}$, Sara Mendez ${ }^{28}$, Maria Rousou $^{29}$, Laurence de Clippele ${ }^{30}$, Annukka Eriksson ${ }^{31}$, Winnie van Zanten ${ }^{32}$, Anna Diamant ${ }^{33}$, Valentina Kirienko Fernandes de Matos ${ }^{34}$

$\left.{ }^{1}\right)$ Monitor Taskforce, Royal Netherlands Institute for Sea Research (NIOZ), Yerseke, Netherlands, $\left.{ }^{2}\right)$ Marine Biological Association, Plymouth, UK, ${ }^{3}$ ) Environmental Hydraulics Institute of the University of Cantabria, Santander, Spain, ${ }^{4}$ ) Senckenberg Gesellschaft für Naturforschung, Biodiversity and Climate Research Centre, Frankfurt am Main, Germany, ${ }^{5}$ ) University of Bologna, Polo di Ravenna, Italy, ${ }^{6}$ ) Department of Ecology and Animal Biology, University of Vigo, Vigo, Spain, ${ }^{7}$ ) Sorbonne Universités, UPMC Univ Paris 6, Station Biologique de Roscoff, Roscoff, France, ${ }^{8}$ ) CNRS, UMR7144 AD2M, Station Biologique de Roscoff, Roscoff, France, ${ }^{9}$ ) CIIMAR, Centro Interdisciplinar de Investigação Marinha e Ambiental, Porto, Portugal, ${ }^{10}$ ) NIB, Marine Biology Station, Piran, Slovenia, ${ }^{11}$ ) Latvian Institute of Aquatic Ecology, Riga, Latvia, ${ }^{12}$ ) Department of Experimental Ecology of Marine Organisms, Institute of Oceanography, University of Gdańsk, Gdynia, Poland, ${ }^{13}$ ) Institute of Oceanology, Polish Academy of Sciences, Sopot, Poland, ${ }^{14}$ ) Stazione Zoologica Anton Dohrn, Naples, Italy, ${ }^{15}$ ) Department of Life and Environmental Sciences, Università Politecnica delle Marche, Ancona, Italy, ${ }^{16}$ ) University of Salento, Lecce, Italy, ${ }^{17}$ ) Faculty of Marine and Environmental Sciences, University of Cádiz, Cádiz, Spain, ${ }^{18)}$ The BITES lab, Center for Advanced Studies of Blanes (CEAB-CSIC), Blanes, Spain, ${ }^{19}$ ) Lomonosov Moscow State University, Moscow, Russia, ${ }^{20}$ ) Institute of Marine Biology, Biotechnology and Aquaculture, Hellenic Centre for Marine Research, Heraklion, Crete, Greece, $\left.{ }^{21}\right)$ University of Copenhagen, Copenhagen, Denmark, ${ }^{22}$ ) Faculty of Fisheries, Ege University, Izmir, Turkey, ${ }^{23}$ ) Department of Nematology, Faculty of Biology, University of Ghent, Belgium, $\left.{ }^{24}\right)$ Hydrobiological Station of Rhodes, Hellenic Centre for Marine Research, Rhodes, Greece, ${ }^{25}$ ) Departamento de Biología de Organismos y Sistemas, Universidad de Oviedo, Oviedo, Spain, ${ }^{26}$ ) Department of Biology, Faculty of Natural Science, University of Tirana, Tirana, Albania, ${ }^{27}$ ) Ecohydros S.L., Santander, Spain, ${ }^{28}$ ) University of Portsmouth, Portsmouth, UK, ${ }^{29}$ ) Marine \& Environmental Research Lab Ltd, Nicosia, Cyprus, ${ }^{30}$ ) Centre for Marine Biodiversity \& Biotechnology, Heriot-Watt University, Edinburgh, United Kingdom, ${ }^{31}$ ) Finnish Environment Institute (SYKE), Marine Centre, Helsinki, Finland, ${ }^{32}$ ) University of Utrecht, Utrecht, Netherlands, ${ }^{33}$ ) Institute of Hydrobiology, National Academy of Sciences of Ukraine, Kyiv, Ukraine, ${ }^{34}$ ) Marine and Environmental Sciences Centre, Universidade dos Açores, Departamento de Oceanografia e Pescas, Horta, Azores, Portugal

*Corresponding author: e-mail: herman.hummel@nioz.nl 


\section{ABSTRACT}

The degree of development and operability of the indicators for MSFD using Descriptor 1 (D1) Biological Diversity was assessed. To this end, an overview of the relevance and degree of operability of the underlying parameters across 20 European countries was compiled by analyzing national directives, legislation, regulations, and publically available reports. Marked differences were found between countries in the degree of ecological relevance as well as in the degree of implementation and operability of the parameters chosen to indicate biological diversity. The best scoring EU countries were France, Germany, Greece and Spain, while the worst scoring were Italy and Slovenia. No country achieved maximum scores for the implementation of MSFD D1. The non-EU countries Norway and Turkey score as highly as the top-scoring EU countries. On the positive side, the chosen parameters for D1 indicators were generally identified as being an ecologically relevant reflection of Biological Diversity. On the negative side however, less than half of the chosen parameters are currently operational. It appears that at a pan-European level, no consistent and harmonized approach currently exists for the description and assessment of marine biological diversity. The implementation of the MSFD Descriptor 1 for Europe as a whole can therefore at best be marked as moderately successful.

\section{KEYWORDS}

Indicators, MSFD, descriptor, marine biodiversity, operability

\section{INTRODUCTION}

From June 2008 the member countries of the European Union (EU) have been working towards the implementation of the Marine Strategy Framework Directive (MSFD). The MSDF aims to provide a holistic and effective mechanism for the protection of the marine environment with the ultimate aim being to achieve Good Environmental Status (GES) of the European marine water bodies by 2020 . The timeline for MSFD implementation includes an initial status assessment (2012); an identification of environmental indicators and targets (2012); establishment of a monitoring programme (2014) and the implementation of a programme of measures towards achieving GES (2016). One of the most challenging aspects of the implementation has been the development of a consistent, scientifically-sound and harmonized approach for describing the marine environment utilising indicators of environmental status at a national and pan-European level. These indicators and their associated targets provide the information required against which the appropriate policy and adaptive management tools can be used to achieve the delicate balance between environmental protection and the sustainable use of the critical marine zone.

Among the positive aspects of implementing the MSFD are that it promotes cooperation among the involved countries and institutions, particularly through the Regional Sea Conventions i.e. the Barcelona Convention for the Mediterranean; Bucharest Convention for the Black Sea; the Oslo-Paris Convention (OSPAR) for the NE Atlantic, and the Helsinki Convention (HELCOM) for the Baltic. The MSFD also promotes the integration of approaches to inventory environmental issues at an international and national level, partly due to its robust legal and obligatory character (Milieu 2014b). It is also intended to provide a more thorough and complete "picture" 
of the marine environment as a whole by complementing earlier directives such as the Water Framework Directive (WFD) for transitional and coastal waters (up to $1 \mathrm{~nm}$ or $3 \mathrm{~nm}$ offshore).

Although the willingness to implement the MSFD may seem high in many countries, in practice there is a wide divergence in the degree to which new indicators and targets have been developed to operationalize the directive. Regarding the development of the indicators, there is a tendency among member states to extract parameters already used for OSPAR or HELCOM, Natura 2000, the Bird Directive or WFD (European Commission, 2012; OSPAR Commission, 2012b; BMUB, 2014c). Although this is necessary as a first step to ensure standardization across the various pieces of legislation, merely limiting the key parameters to those used in previous instruments would undermine the spirit and usefulness of the (new) MSFD directive.

A current key question therefore is to what extent are the GES descriptors and their underlying indicators developed in the different European countries. Moreover, since many countries are relying heavily on indicators and associated parameters from earlier directives, the question arises to what extent these parameters are relevant to the overlying descriptor. Both these questions are important as reported legal compliance with the directive presented as progress (against the MSFD milestones) may mask underlying issues with the basic science needed to report on progress towards GES.

The aim of the current study therefore was to assess the degree of development and operability of the indicators for MSFD using Descriptor 1 (D1) Biological Diversity as a test case. Descriptor D1 is a key descriptor focusing on whether Biological Diversity is maintained, and should be able to show whether the quality and occurrence of habitats and the distribution and abundance of species are in line with prevailing physiographic, geographic and climatic conditions (Directive 2008/56 EC ${ }^{1}$; European Commission, 2011). Good Environmental Status for Descriptor 1 should be achieved by ensuring on the one hand no further loss of the diversity of genes, species and habitats/communities at ecological relevant scales and, on the other hand, that deteriorated components, where intrinsic environmental conditions allow, are restored to target levels.

The assessment of MSFD D1 Biological Diversity parameters was carried out by compiling an overview of the relevance and degree of operability of the parameters across different European countries.

The difficulty of accessing all the relevant information means the study is not exhaustive but the large number of countries involved means it should be comprehensive enough to provide a unique assessment of the relative progress across member states.

\section{MATERIAL AND METHODS}

\section{Information Collation}

A survey of 20 European countries was conducted to determine the actual status and degree of development of Descriptor 1 of the MSFD. The survey was undertaken by compiling and analyzing national directives, legislation, regulations, and publically available reports. Where

\footnotetext{
${ }^{1}$ Directive 2008/56/EC Establishing a framework for community action in the field of marine environmental policy (Marine Strategy Framework Directive) http://eur-lex.europa.eu/legalcontent/EN/TXT/PDF/?uri=CELEX:32008L0056\&from=EN
} 
feasible, the available information was supplemented with interviews of experts from ministries and research institutes.

As some countries voluntarily have adopted the MSFD Descriptor system or installed homologous systems, the survey was extended with some neighbor-countries of the EU to assess the degree of concurrence or differentiation of those countries with the EU.

Descriptor 1 'Biological Diversity' is comprised of 7 criteria each including a range of associated indicators (or 'types' of indicators) for which parameters have been developed. Most countries have developed the indicators by breaking down the ecosystem into several components or features (i.e. functional groups and categories of taxa or habitats) (Cochrane, 2010; European Commission, 2011) (see Table 1) the key ones being Marine Mammals; Fish; Birds; Benthos; Pelagic habitats; Rock and biogenic reef habitats; Sediment habitats; and Other habitats. This results in about 40 "State Variables", also called Parameters or Metrics (OSPAR Commission, 2012a; henceforth referred to as 'parameters') $)^{2}$, to be classified for D1. Since not every country develops parameters for the same component set, the number of Parameters may differ slightly between countries. The assessment omitted components for which few (less than 6) countries have developed parameters such as jellyfish, turtles and cephalopods.

\section{Analysis of information}

Two criteria were used to assess the indicators as described below. The evaluation was firstly carried out in May 2013, and updated from May 2014 onwards by scientists assembled in two meetings as part of the EMBOS network (COST Action ES1003 on the European Marine Biodiversity Observatory System).

\section{CRITERION 1}

Firstly, the ecological relevance of a parameter proposed by each country was assessed as to its ecological relevance, i.e. how realistically it was likely to represent the impacts of the state of the natural species or community diversity or the natural habitats in an area. The two key determinants when considering this were firstly, whether a parameter is easy to measure or not and secondly how representative a parameter is of the structural and functional state of diversity in a coastal system. For the latter determinant, an additional consideration is how sensitive the parameter is to stressors and other impacts so state change can be identified. The indicators were classified on a scale representing not relevant (0); somewhat relevant (1); definitely relevant (2).

For example, the presence of a specific rare seabird species (as in Italy; MATTM, 2009), which is difficult to observe, would not be deemed as being a proper ecological measure of the diversity of a coastal system, both due to the problems with measuring the parameter and in being a poor link to the state of the coastal biodiversity it is supposed to be an indicator for. Thus the parameter would be judged as not relevant (0) or at most somewhat relevant (1). In contrast, parameters based on multivariate measures of diversity are more likely to be representative of

\footnotetext{
${ }^{2}$ OSPAR Commission 2012a, p. 113: A parameter or metric is a measureable single characteristic of a species or habitat (e.g. number of individuals, biomass in g dry weight, sediment particle size diameter in mm). Parameters of this nature can be used as simple indicators, and indeed several such metrics are included in the list of indicators provided in the Commission Decision on criteria and indicators (e.g. indicator 1.2.1, population biomass).
} 
the biological diversity of the habitat and can be linked to pressures through known effects on biodiversity.

In most cases, the ecological relevance of the indicator was based on the expert judgment of the scientists undertaking the assessment supplemented with information from the literature on the importance given to the different parameters (e.g. for Spain: Borja et al., 2011; Velasco et al., 2012).

\section{CRITERION 2}

The second criterion for the assessment was the degree of operability of a parameter. Parameters were considered as not being operational when they were either still under discussion by member states or not being taken forward at all at the present time, in which case they were assigned a score of 0 . If a parameter is in development (e.g. R\&D is being carried out to operationalize it) then it was assigned a score of 1 . Finally, if an indicator is already operational then it was assigned a score of 2.

The sum of the scores was calculated with the score for each parameter ranging from 0 to 4 . A combined score of 0 means that the parameter is currently not deemed to be implemented or is poorly implemented at best; a score of 4 means the parameter is being well implemented by that member state.

\section{RESULTS AND DISCUSSION}

Marked differences were found between countries in the degree of ecological relevance as well as in the degree of implementation and operability of the parameters chosen to indicate biological diversity (Figure 1, Table 2).

The first thing to notice in the results of the evaluation is the wide disparity between countries in the implementation of D1 via its parameters. There is also variation within countries with some functional components and some indicator classes are better developed than other. For example, in the Netherlands, Norway and Poland some clusters of related parameters are considered relevant and operational while other clusters are neither relevant nor operational. It is also noticeable that in certain countries such as Turkey, relevant parameters have been developed for almost all groups but with a relatively low degree of operationalization. This variation illustrates strong differences between countries in their strategies for developing this descriptor, some developing parameters that are relevant and largely operational, whereas other focusing on the development of a wider range of (theoretical) parameters but which are far from being made operational.

These differences between countries are corroborated by the German National Measuring Programme (BLMP, 2014) stating that the listed German indicators are at different stages of development, some being operational, while others are lacking evaluation criteria and/or monitoring.

Even some differences have been identified across sub-regions within the same country. The same way, indicators and descriptors have not been implemented/assessed in all the regions of a country (e.g. Spain). 
The EU countries that scored highest in the evaluation were France, Germany, Greece and Spain, those scoring lowest were Italy and Slovenia (Figure 1, Table 2). No country achieved maximum scores by demonstrating that its parameters were all ecologically relevant (thus scientifically robust) and operational.

Among countries not belonging to the EU the results also vary. In Ukraine and Albania, for example, the implementation of instruments homologous to the MSFD seems to be rather lacking as they are not obliged to follow the EC regulation. In contrast, Turkey and Norway although also under no obligation, have chosen to implement the MSFD. Both these countries are among the highest scoring in the evaluation meaning that they have outperformed many EU countries that were legally required to transpose the directive.

Although the MSFD descriptor for biodiversity appears to be well-developed with at least 40 parameters, the evaluation as undertaken for this study reveals serious weaknesses in many of the parameters in terms of ecological relevance. Many of the parameters are no more than general qualitative statements with little quantitative underpinning or information on species groups (e.g. changes of plankton form-types, or presence of monk seal). Moreover, as the development of the indicators and underlying parameters is often based on previously available data, the degree of development is strongly biased in favor of species of commercial interest (e.g. proportion of large fish) or endangered species or habitats: these may not necessarily reflecting wider marine biodiversity. Such a biased approach, often top-down (politically) driven, resulted in low numbers of relevant parameters for biological diversity (as in the Netherlands), yielding a low average score. On the other hand, in countries where in-depth consultations with experts have taken place, such a bottom-up process can result in the selection of relevant biodiversity parameters. Yet, a low degree of operationalization, as e.g. for Turkey having a very high score for relevance, may yield again a somewhat lower average score.

Other reasons for low performance of parameters and the wide disparity in performance deduced from the country reports to the EU or similarly relevant documentation include the lack of clear and shared homologous definitions on the criteria whereby the choice of parameters relied more on (expert) opinion than on true data. As Palialexis et al. (2014) stated, although some indicators of D1 are very clear and specific (e.g. 1.2.1 Population abundance and/or biomass) having a straight-forward implementation, many other are more sophisticated and general (as e.g. 1.7.1 Composition and relative proportions of ecosystem components); more open to interpretation and reliant on a suite of methods and models to be implemented. Even for established parameters there may be major knowledge gaps and a lack of quantification of the targets (e.g. threshold level values) for what is, or is not, GES (Milieu, 2014b). The lack of shared definitions can be overcome by collaboration between member states. In certain cases however, lack of collaboration and coordination between governmental and research institutions, or lack of communication among regions within each country, and even conflicts between scientists and policy makers were also mentioned in interviews as a reason for a delayed development of GES indicators. A complex reporting structure and lack of funding for reaching more detailed and advanced results was often pointed out too in the interviews. 
As a consequence of all these flaws in the establishment and implementation of the GES indicators and underlying Parameters, for Europe as a whole, the average combined score (for all 40 Parameters of all 20 countries) is only 1.9 (out of a score of maximally 4). This means that the performance of most European countries with regard to the implementation of the MSFD is still far below that necessary if GES is truly to be achieved. There is also an urgent need for harmonised monitoring networks and standardized sampling strategies, for a full implementation of the MSFD to all European countries, as advocated by e.g. the COST Action EMBOS (Heip \& McDonough, 2012, p. 19). This would facilitate the establishment of a proper internationally integrated set of parameters, and allow a full gaps and weakness analysis to be undertaken.

In conclusion, even though it is clear a lot of effort has gone in to ensuring parameters are ecologically relevant reflections of Biological Diversity, the real weakness is in the lack of operational indicators: less than half of the established Parameters at this point in the process are operational. There also needs to be more effort for coordination at the pan-European level so a consistent and harmonized approach to describing marine biological diversity with comparable parameters can be developed. Although a couple of countries are on track in implementing the MSFD, our results suggest that several European countries are not properly prepared to introduce the MSFD, partly because in those countries most parameters are neither bottom-up science driven, nor well-described. Therefore, the implementation of the MSFD Descriptor 1 can for Europe as a whole only be marked as moderate. Ultimately, the need to summarize the large environmental variability and assess impacts using a relatively small group of parameters is a hugely ambitious task. From a scientific point of view, several parameters are still under development because of the need to better understand the functional relationships between biological and abiotic factors, or on how to discriminate between the natural variability of the ecological systems in space and time and the shifts caused by human pressures. Official reports may contain parameters and monitoring as required for legal obligations but the need to scrutinize the scientific robustness of the MSFD work is more crucial than ever.

\section{FINANCIAL SUPPORT AND ACKNOWLEDGEMENTS}

Meetings to prepare this paper were made possible by funding through COST Action ES1003 EMBOS on the Development and Implementation of a Pan-European Marine Biodiversity Observatory System. Carlos Castellanos Perez Bolde acknowledges MARES Grant FPA 2011-0016 under the Erasmus Mundus framework, Marlene Jahnke has been supported by a SZN PhD fellowship, and João N. Franco by Portuguese PhD FCT grant SFRH/BD/84933/2012. The authors wish to thank Victor Yasynsky, Oksana Savenko (Schmalhausen Institute of Zoology, Kiev, Ukraine), Juha-Markku Leppänen, Jan-Erik Bruun, Samuli Korpinen (Finnish environment institute, SYKE, Helsinki, Finland), and Martina Orlando Bonaca (Marine Biology Station, Piran, Slovenia) for their contributions.

\section{REFERENCES:}

Anistratenko V.V., Anistratenko O. and Haliman I.A. (2007) The composition of the mollusk fauna of the Azov Sea as a function of its salinity regime. Reports of the National Academy of Sciences of Ukraine, 4, 161-166 (in Russian). 
Anonymous (1985) Environmental studies in engineering prospecting on the continental shelf. RD 51 11-01-85, 110 pp. (in Russian).

Anonymous (2010) Ley 41/2010, de 29 de diciembre, de protección del medio marino. Boletín Oficial del Estado, Núm. 317 (Jueves 30 de diciembre de 2010), Sec. I., 108464-108488.

Arcos J.M., Bécares J., Cama A. and Rodríguez B. (2012) Estrategias Marinas. Grupo Aves. Evaluación inicial y buen estado ambiental. D. de Armas, J. Bellas \& L. Gil de Sola (Coords.). Ministerio de Agricultura, Alimentación y Medio Ambiente, Secretaría General Técnica, Centro de Publicaciones, Madrid, $296 \mathrm{pp}$.

Aslaksen I. and Garnåsjordet P.A. (2012) The Norwegian Nature Index, Norsk Geografisk Tidsskrift -Norwegian Journal of Geography, 66:5, 239-240.

Aslaksen I., Framstad E., Garnåsjordet P.A., Nybø S. and Skarpaas O. (2012) Knowledge gathering and communication on biodiversity: Developing the Norwegian Nature Index, Norsk Geografisk Tidsskrift - Norwegian Journal of Geography, 66:5, 300-308.

Belgische Staat (2012) Omschrijving van Goede Milieutoestand en vaststelling van Milieudoelen voor de Belgische mariene wateren. Kaderrichtlijn Mariene Strategie - Art 9 \& 10. BMM, Federale Overheidsdienst Volksgezondheid, Veiligheid van de Voedselketen en Leefmilieu, Brussel, België, 34 pp.

BLMP (2014) Entwicklung nationaler Indikatorlisten für die Nord- und Ostsee, Sachstand 07.03.2014. Bund-Länder Messprogramm, 11 pp.

BMUB (2014a) Reporting requirement on monitoring programmes under MSFD Article 11 (Baltic Sea). Federal Ministry for the Environment, Building, Nature Conservation and Nuclear Safety. Web questionnaire with reporting date: 2014-10-15 (with amendments to D10 from 201411-5) (http://cdr.eionet.europa.eu/de/eu/msfd_mp/balde), 73 pp. (partially in German).

BMUB (2014b) Reporting requirement on monitoring programmes under MSFD Article 11 (The Greater North Sea, including the Kattegat, and the English Channel). Federal Ministry for the Environment, Building, Nature Conservation and Nuclear Safety. Web questionnaire with reporting date: 2014-10-15 (with amendments to D10 from 2014-11-5) (http://cdr.eionet.europa.eu/de/eu/msfd_mp/ansde), 73 pp. (partially in German). BMUB (2014c) Umsetzung der Meeresstrategie-Rahmenrichtlinie RICHTLINIE 2008/56/EG zur Schaffung eines Ordnungsrahmens für Maßnahmen der Gemeinschaft im Bereich der Meeresumwelt (Meeresstrategie-Rahmenrichtlinie). Überwachungsprogramme gemäß § $45 f$ Abs. 1 WHG zur Umsetzung von Art. 11 MSRL - Teil A - Rahmenkonzept. Bundesministerium für Umwelt, Naturschutz, Bau und Reaktorsicherheit. Referat WA I 5 Meeresumweltschutz, Internationales Recht des Schutzes der marinen Gewässer, 104 pp.

Borja Á., Galparsoro I., Irigoien X., Iriondo A., Menchaca I., Muxika I., Pascual M., Quincoces I., Revilla M., Rodríguez J.G., Santurtún M., Solaun O., Uriarte A., Valencia V.and Zorita I. (2011) Implementation of the European Marine Strategy Framework Directive: A methodological approach for the assessment of environmental status, from the Basque Country (Bay of Biscay). Marine Pollution Bulletin, 62, 889-904.

Burrows M.T., Mieszkowska N. and Hawkins S.J. (2014a). Marine Strategy Framework Directive Indicators for UK Rocky Shores. Part 1: Defining and Validating the Indicators. JNCC Report, 522, SAMS/MBA/NOCS for JNCC, JNCC Peterborough, $98 \mathrm{pp}$.

Burrows M.T., Smale D., O'Connor N. and Van Rein H. (2014b) Marine Strategy Framework Directive Indicators for UK Kelp Habitats. Part 1: Developing Proposals for Potential Indicators. JNCC Report, 525, SAMS/MBA/QUB/UAber for JNCC, JNCC Peterborough, 80 pp. 
Certain G., Skarpaas O., Bjerke J.W., Framstad E. and Lindholm M. (2011) The Nature Index: A General Framework for Synthesizing Knowledge on the State of Biodiversity. PLOS ONE, 6(4), e18930.

Cima F. and Ballarin L. (2013) A proposed integrated bioindex for the macrofouling biocoenosis of hard substrata in the lagoon of Venice. Estuarine, Coastal and Shelf Science, 130, 190-201.

Cochrane S.K.J., Connor D.W., Nilsson P., Mitchell I., Reker J., Franco J., Valavanis V., Moncheva S., Ekebom J., Nygaard K., Serrão Santos R., Narberhaus I., Packeiser T., van de Bund W. and Cardoso A.C. (2010) Marine Strategy Framework Directive - Task Group 1 Report Biological diversity. JRC Scientific and Technical Reports, Joint Research Centre, EUR 24337, $111 \mathrm{pp}$.

Cook A.S.C.P., Ross-Smith V.H. and Robinson R.A. (2012) Development of MSFD Indicators, Baselines and Target for Seabird Breeding Failure Occurrence in the UK. BTO Research Report, 615, British Trust for Ornithology for JNCC, JNCC Peterborough, 94 pp.

COREM (2012) La tutela della biodiversità marina in Mediterraneo, esperienze a confronto. Progetto COREM "Cooperacione delle Reti Ecologiche del Mediterraneo", Portoferraio, 30 pp. DEFRA (2014) Marine Strategy Part Two: UK Marine Monitoring Programmes. Department for Environment, Food and Rural Affairs, $86 \mathrm{pp}$.

DFMR (2012a) Initial Assessment of the Marine Environment of Cyprus, Part I - Characteristics: Implementation of Article 8 of the Marine Strategy Framework-Directive (2008/56/EC). Department of Fisheries and Marine Research, Ministry of Agriculture, Natural Resources and the Environment, Nicosia, Cyprus, 273 pp.

DFMR (2012b) Determination of Good Environmental Status of the Marine Environment of Cyprus: Implementation of Article 9 of the Marine Strategy Framework-Directive (2008/56/EC). Department of Fisheries and Marine Research, Ministry of Agriculture, Natural Resources and the Environment, Nicosia, Cyprus, 90 pp.

DFMR (2012c) Environmental Targets and Associated Indicators. Implementation of Article 10 of the Marine Strategy Framework-Directive (2008/56/EC). Department of Fisheries and Marine Research, Ministry of Agriculture, Natural Resources and the Environment, Nicosia, Cyprus, 33 pp.

DFMR (2014a) Revision of Reports prepared in 2012 for the implementation of Articles 8, 9 and 10 of the Marine Strategy Framework-Directive (2008/56/EC). Department of Fisheries and Marine Research, Ministry of Agriculture, Natural Resources and the Environment, Nicosia, Cyprus, 74 pp.

DFMR (2014b) Report on the Monitoring Programmes of Cyprus in the framework of the implementation of the Marine Strategy Framework Directive (2008/56/EC). Department of Fisheries and Marine Research, Ministry of Agriculture, Natural Resources and the Environment, Nicosia, Cyprus, 154 pp.

DME (2012) Danmarks Havstrategi - Miljømålsrapport. Danish Ministry of the Environment, Nature Agency, 46 pp.

DME (2014) Danmarks Havstrategi - Overvågningsprogram. Danish Ministry of the Environment, Nature Agency, 53 pp.

Dupont C, Belin A., Vermonden B., Moreira G., Cochrane S., Wilson L., Emblow C., Kater B., Des Clercs S., Parr W., Le Visage C., Green N., Cools J., Thomsen F. (2014) Article 12 Technical assessment of the MSFD 2012 obligations. France. Final version. Milieu Ltd, Brussels, $67 \mathrm{pp}$. 
État Belge (2012) Définition du bon état écologique et définition d'objectifs environnementaux pour les eaux marines Belges. Directive-cadre Stratégie pour le milieu marin - Art $9 \& 10$. UGMM, Service Public Fédéral Santé publique, Sécurité de la Chaîne alimentaire et Environnement, Bruxelles, Belgique, $32 \mathrm{pp}$.

European Commission (2011). Relationship between the initial assessment of marine waters and the criteria for good environmental status. Commission staff working paper. European Commission, Brussel. SEC (2011) 1255 final, 95 pp.

European Commission (2012). Links between the Marine Strategy Framework Directive (MSFD 2008/56/EC) and the Nature Directives (Birds Directive 2009/147/EEC (BD) and Habitats Directive 92/43/EEC (HD)). Interactions, overlaps and potential areas for closer coordination. European Commission, Brussel, 31 pp.

Fariñas-Franco J.M., Pearce B., Porter J., Harries D., Mair J.M., Woolmer A.S. and Sanderson W.G. (2014) Marine Strategy Framework Directive Indicators for Biogenic Reefs formed by Modiolus modiolus, Mytilus edulis and Sabellaria spinulosa. Part 1: Defining and Validating the Indicators. JNCC Report, 523, Heriot Watt University for JNCC, JNCC Peterborough, 276 pp.

Gil J., Ramos F., Jiménez M.P., Silva L., Baldó F., Farias C., Sobrino I., Burgos C., Serrano A., Velasco F., Punzón A., Tello O., Lens S., Macías D., Bellas J., Coján M., Aguirre E., Módica L., González-Irusta J.M. and Díaz V. (2012) Estrategia Marina. Demarcación Marina Sudatlántica. Parte IV. Descriptores del buen estado ambiental. Descriptor 1: Biodiversidad. Evaluación inicial y buen estado ambiental. D. de Armas \& J. Bellas (Coords.). Ministerio de Agricultura, Alimentación y Medio Ambiente, Secretaría General Técnica, Centro de Publicaciones, Madrid, $425 \mathrm{pp}$.

Gil de Sola L., Serrano A., Velasco F., Punzón A., Preciado I., Ordines F., Ruiz J.M., Acosta J., Lens S., Macías D., Tello O., González-Irusta J.M., García J.E., Módica L. and Díaz V. (2012) Estrategia Marina. Demarcación Marina del Estrecho y Alborán. Parte IV. Descriptores del buen estado ambiental. Descriptor 1: Biodiversidad. Evaluación inicial y buen estado ambiental. D. de Armas \& J. Bellas (Coords.). Ministerio de Agricultura, Alimentación y Medio Ambiente, Secretaría General Técnica, Centro de Publicaciones, Madrid, 615 pp.

Gladilina E.V. (2010) Observations of cetaceans (Cetacea) in the waters of Karadag nature reserve and theadjacent waters. Scientific Notes of Taurida V.I. Vernadsky National University. Series: Biology, Chemistry 25, 2, 51-59 (in Russian).

Guérin L., Feunteun E., Gremare A., Beauvais S., Gailhard-Rocher I., Grall J., Labrune .C, Laurand S., Lavesque N., Lejart M., Paillet J., Personnic S., Quemmerais-Amice F., Sterckeman A., Robinet T. and You H. (2013). "Définition du programme de surveillance et plan d'acquisition de connaissances pour la DCSMM: propositions scientifiques et techniques (chantier 2). Thématique 1: Biodiversité". MNHN-Service des stations marines, RESOMAR, $A A M P, 212$ pp. + annexes.

Guide to hydrological work in the oceans and seas (1977). Gidrometeoizdat, Leningrad, 725 pp. (in Russian).

Haynes T., Bell J., Saunders G., Irving, R. Williams J. and Bell G. (2014) Marine Strategy Framework Directive Shallow Sublittoral Rock Indicators for Fragile Sponges and Anthozoan Assemblages. Part 1: Developing Proposals for Potential Indicators. JNCC Report, 524, Nature Bureau and Environment Systems Ltd. for JNCC, JNCC Peterborough, 85 pp. 
Heip C. and McDonough N. (2012) Marine Biodiversity: A Science Roadmap for Europe. Marine Board Future Science Brief 1, European Marine Board, Ostend, Belgium, 36 pp.

Hernández C.L., Serrano A., García-Santamaría M.T., Perales C., Martín-Sosa P., Alayón P.P., Jiménez S., Tello O., Lens S., Macías D., González J.G., Rodríguez J.E. and Díaz V. (2012). Estrategia Marina. Demarcación Marina Canaria. Parte IV. Descriptores del buen estado ambiental. Descriptor 1: Biodiversidad. Evaluación inicial y buen estado ambiental. D. de Armas \& J. Bellas (Coords.). Ministerio de Agricultura, Alimentación y Medio Ambiente, Secretaría General Técnica, Centro de Publicaciones, Madrid, 264 pp.

ICES (2013). Report of the Joint ICES/OSPAR Expert Group on Seabirds (WGBIRD), 22-25 October 2013, Copenhagen, Denmark. ICES CM 2013/ACOM:78, 77 pp.

ISPRA (2013). Proposte per la definizione del buono stato ambientle e dei traguardi ambientali. Descrittore 1 Biodiversità. ISPRA, 110 pp.

Krzymiński W. (2013) Wstępna ocena stanu środowiska wód morskich polskiej strefy Morza Bałtyckiego. Raport do Komisji Europejskiej. Departament monitoringu i informacji o środowisku, GIOŚ, 463 pp.

Krzymiński W. (2014) Zestaw właściwości typowych dla dobrego stanu środowiska wód morskich. Raport do Komisji Europejskiej. [Set of features peculiar to good condition of marine water environment. Report to European Commission.] Departament monitoringu i informacji o środowisku, GIOŚ, 21 pp.

LHEI (2012) Jūras stratēǵijas pamatdirektīva 2008/56/EK. Jūras vides stāvokḷa sākotnējais novērtējums - Laba vides stāvokḷa kritēriji, indikatori un vērtējums Rīgas līcim un Baltijas jūrai. Latvijas Hidroekoloǵijas institūts, Rīga, Latvija, 18 pp.

LHEI (2014) Latvijas piekrastes un pārejas ūdeṇu (Baltijas jūras) bioloǵisko kvalitātes elementu (fitoplanktona, makrofïtu, bentosa bezmugurkaulnieku faunas, zivju) klašu robežu izstrāde (ES Ūdens Struktūrdirektīva 2000/60/EK). Projekta ziṇojums. Latvijas Hidroekoloǵijas institūts, Rīga, Latvija, 45 pp.

Losovskaya G.V. (2005) Change of some parameters (dominance and diversity) for the species structure of the Mytilus galloprovincialis biocenosis under hypoxic and fish die-off conditions in the north-western part of the Black Sea. Ecological safety of coastal and shelf zones and complex use of shelf resources, 12, 574-580 (in Russian).

MAGRAMA (2014) Estrategias Marinas. VI. Programas de Seguimiento. Documento 1: Indicadores. Ministerio de Agricultura, Alimentación y Medio Ambiente. 92 pp + annexes.

MAMAOT (2012) Estratégia Marinha para a subdivisão do Continente. Diretiva Quadro Estratégia Marinha. Ministério da Agricultura, do Mar, do Ambiente e do Ordenamento do Território, Portugal, 930 pp.

MAMAOT (2014) Estratégias Marinhas para as Àguas Marinhas Portuguesas. Versão para consulta pública Outubro de 2014. Diretiva Quadro Estratégia Marinha. Ministério da Agricultura, do Mar, do Ambiente e do Ordenamento do Território, Portugal, 164 pp.

MARMONI (2014) List of new, innovative and cost-effective indicators for monitoring biodiversity in the Baltic Sea. MARMONI project report. Baltic Environmental Forum, 164 pp.

MATTM (2009) Convenzione sulla Diversità Biologica $-4^{\circ}$ Rapporto Nazionale. Ministero dell'Ambiente e della Tutela del Territorio e del Mare, Italy, 138 pp.

MATTM (2010) La Strategia Nazionale per la Biodiversità. Ministero dell'Ambiente e della Tutela del Territorio e del Mare, Italy, 204 pp. 
MEECC (2014) National Strategy \& Action Plan for Biodiversity [In Greek]. Ministry of Environment, Energy and Climate Change, Greece, 130 pp.

MENRU (2010) The Convention about biodiversity. The forth national report of Ukraine. Ministry of Ecology and Natural Resources of Ukraine, Kiev, 80 pp. (in Russian).

MFWM (2008) National Biodiversity Strategy and Action Plan (In Turkish). Ministry of Forest and Water Management, General Directorate of Natural Conservation and National Parks, Ankara, 176 pp.

MIE (2012) Marine Strategy for the Netherlands part of the North Sea 2012-2020, Part 1, Ministry of Infrastructure and the Environment, $140 \mathrm{pp}$.

MIE (2014) The Draft Marine Strategy for the Dutch part of the North Sea 2012-2020, Part 2. MSFD Monitoring Programme version 04.02.2014. Ministry of Infrastructure and the Environment, $21 \mathrm{pp}$.

Mikhalev Y.A. (2008) Characteristics of distribution of the common dolphins, Delphinus delphis (Cetacea), in the Black Sea. Vestnik zoologii 42, 325-337 (in Russian).

Milieu (2014a) Article 12 Technical Assessment of the MSFD 2012 obligations. Italy. Milieu Ltd Consortium, Belgium, $46 \mathrm{pp}$.

Milieu (2014b) Article 12 Technical Assessment of the MSFD 2012 obligations. National Report: Spain. Milieu Ltd Consortium. Belgium, 69 pp.

Munari C. and Mistri M. (2010). Towards the application of the Water Framework Directive in Italy: Assessing the potential of benthic tools in Adriatic coastal transitional ecosystems. Marine Pollution Bulletin, 60, 1040-1050.

Nybø S., Certain G. and Skarpaas O. (2011) The Norwegian Nature Index 2010. DN-report, 2011, 1, $24 \mathrm{pp}$.

Nybø S., Certain G. and Skarpaas 0. (2012) The Norwegian Nature Index - state and trends of biodiversity in Norway, Norsk Geografisk Tidsskrift - Norwegian Journal of Geography, 66, 5, 241-249.

OSPAR Commission (2012a) MSFD Advice Manual and Background Document on Biodiversity. A living document - Version 3.2 of 5 March 2012. Approaches to determining Good Environmental Status, setting of environmental targets and selecting indicators for Marine Strategy Framework Directive descriptors 1, 2, 4 and 6. OSPAR Commission Publication, 581, $141 \mathrm{pp}$.

OSPAR Commission (2012b) Report of the OSPAR workshop on MSFD biodiversity descriptors: comparison of targets and associated indicators. ISBN 978-1-909159-09-9, OSPAR Commission Publication, 575, 56 pp.

OSPAR Commission (2013) OSPAR special request on review of the technical specification and application of common indicators under D1, D2, D4 and D6. ICES Advice, 1, 14 pp.

Palialexis A., Tornero V., Barbone E., Gonzalez D., Hanke G., Cardoso A.C., Hoepffner N., Katsanevakis S., Somma F. and Zampoukas N. (2014) In-Depth Assessment of the EU Member States' Submissions for the Marine Strategy Framework Directive under articles 8, 9 and 10. Institute for Environment and Sustainability, Joint Research Centre, European Commission, Luxembourg, $153 \mathrm{pp}$.

Peterlin M., Bremec U., Centa M., Bruderman B., Gabrijelčič E., Gosar L., Kramar M., Mohorko T., Palatinus A., Petelin Š., Urbanič G., Orlando-Bonaca M., Lipej L., Malej A., Francé J., Čermelj B., Bajt O., Kovač N., Mavrič B., Turk V., Mozetič P., Ramšak A., Kogovšek T., Šiško M., Flander Putrle V., Grego M., Tinta T., Petelin B., Vodopivec M., Jeromel M., Martinčič 
U., Malačič V., Marčeta B., Pengal P., Deželak F.and Jenko J. (2013) Management plan of marine environment: description of good marine environmental status and environmental objective. Inštitut za vode Republike Slovenije, Ljubljana, 36 pp. (in Slovenian).

Petrenko O. A. (2013) Main results of complex research in the Azov-Black Sea basin and the World Ocean. Southern Scientific Research Institute of Marine Fisheries and Oceanography (YugNIRO), Kerch, $166 \mathrm{pp}$.

Ruiz J.M., Massutí E., Ordines F., Quetglas A., Moranta J., Ramos A., Barcala E., Franco I., Gil de Sola L., García J.E., Macías D., Lens S., Deudero S., Vázquez M., Bellas J., Mas J., Giménez F., Gomariz F., de la Ossa J.A., del Pilar-Ruso Y., Ramos A., Sánchez J.L., Garrido D., Rodríguez J.C., González-Irusta J.M., García J.E., Farriols M.T. and Díaz V. (2012). Estrategia Marina. Demarcación Marina Levantino-Balear. Parte IV. Descriptores del buen estado ambiental . Descriptor 1: Biodiversidad. Evaluación inicial y buen estado ambiental. D. de Armas \& J. Bellas (Coords.). Ministerio de Agricultura, Alimentación y Medio Ambiente, Secretaría General Técnica, Centro de Publicaciones, Madrid, 839 pp.

Santos Vázquez B, Read F, Saavedra C, Lens S., Stephanis R. de, Giménez Verdugo J., Verborgh P., Gauffier P., Esteban Pavo R., García Tiscar S., Salazar Sierra J.M., Jiménez C., López A.,. Martínez Cedeira J.A, Llanova A., Covelo P., Vázquez Bonales J.A., Laria L., Marcos Ipiña E., Salazar Sierra J., Maestre I., Cañadas A., Moreno P., Murcia J.L., Martín V., Raga J.A., Gozalbes Aparicio P., Aguilar Vila A., Learmonth J., Fernández R., Pierce G.J., Sagarminaga R., Urquiola Pascual E., Ruano A. and Areces J.J. (2012) Estrategias Marinas. Grupo Mamíferos Marinos. Evaluación inicial y buen estado ambiental. J. Bellas, B. Santos Vázquez $\&$ R. de Stephanis (Coords.). Ministerio de Agricultura, Alimentación y Medio Ambiente, Secretaría General Técnica, Centro de Publicaciones, Madrid, 448 pp.

Şekeroğlu C, Anderson S., Akçay E., Bilgin R., Can Ö. E., Semiz G., Tavşanoğlu Ç., Yokeş M. B., Soyumert A., İpekdali K., Sağlam İ.K., Yücel M. and Dalfesm N. (2011) Turkey's globally important biodiversity in crisis. Biological Conservation, 144, 2752-2769.

SRMC (2014) Plan d'action pour le milieu marin. Programme de surveillance. Sous-Région Marine Mers Celtiques. Projet de programme de surveillance soumis à la consultation des instances, 18 août 2014, 327 pp.

SRMG (2014) Plan d'action pour le milieu marin. Programme de surveillance. Sous-Région Marine Golfe de Gascogne. Projet de programme de surveillance soumis à la consultation des instances, 18 août 2014, 332 pp.

SRMM (2014) Plan d'action pour le milieu marin. Programme de surveillance. Sous-Région Marine Manche-mer du Nord. Consultation du 18 août au 17 novembre 2014, 363 pp.

Sumer V. and Muluk C. (2011) Challenges for Turkey to Implement the EU Water Framework Directive. Turkey's Water Policy, 43-67.

SYKE (2012) The assessment of the current state of the sea environment, determination of the characteristics of good environmental status, targets and indicators. The Finnish Environment Institute (SYKE), 19.10.2012, 42 pp. (in Finnish).

SYKE (2014) Indicators of the marine strategy framework directive in Finland. Working document (Excel). The Finnish Environment Institute (SYKE), 24.11.2014, 1 p.

Tunesi L., Casazza G., Dalù M., Giorgi G. and Silvestri C. (2013). The implementation of the marine strategy framework directive in Italy: Knowledge to support the management. Biologia Marina Mediterranea, 20, 35-52. 
UNEP/MAP (2007) Report on marine pollution indicators in Mediterranean Countries. UNEP(DEPI)/MED WG. 316/Inf.11, 62 pp.

Velasco F., Serrano A., Punzón A., Lens S., Nogueira E., González-Quirós R., Tello O., Macías D., Módica L., González-Irusta J.M., Airbe E. and Díaz V. (2012) Estrategia Marina. Demarcación Marina Noratlántica. Parte IV. Descriptores del buen estado ambiental. Descriptor 1: Biodiversidad. Evaluación inicial y buen estado ambiental. D. de Armas \& J. Bellas (Coords.). Ministerio de Agricultura, Alimentación y Medio Ambiente, Secretaría General Técnica, Centro de Publicaciones, Madrid, $680 \mathrm{pp}$.

Vishnyakova K. and Gol'din P. (2014) Seasonality of strandings and bycatch of harbour porpoises in the Sea of Azov: the effects of fisheries, weather conditions, and life history. ICES Journal of Marine Science, $192 \mathrm{pp}$.

VNIRO (2004) Instructions and guidelines for biological information collection and processing in the European North Sea and the North Atlantic. All-Russia Institute of Marine Fisheries and Oceanography, 299 pp. (in Russian).

Zamora V.V., Snigirev S.M., Kurakin A.P. and Oleinik Y.N. (2005) Species composition and distribution of fish in the area of Snake Island. Ecological safety of coastal and shelf zones and complex use of shelf resources, 12, 593-602 (in Russian). 
Table 1. Overview of the criteria, indicators and most common groups for which Parameters are described with regard to Descriptor D1 Biological Diversity (codes are used in Table 2).

\begin{tabular}{|c|c|c|}
\hline Criteria & Indicator & Group \\
\hline \multirow{9}{*}{$\begin{array}{l}1.1 \\
\text { Species } \\
\text { distribution }\end{array}$} & \multirow[t]{4}{*}{ Distributional range (1.1.1) } & a. Mammals \\
\hline & & b. Fish \\
\hline & & c. Benthos \\
\hline & & d. Birds \\
\hline & \multirow[t]{4}{*}{ Distributional pattern within the latter (1.1.2) } & a. Mammals \\
\hline & & b. Fish \\
\hline & & c. Benthos \\
\hline & & d. Birds \\
\hline & Area covered by the species (1.1.3) & Benthos \\
\hline \multirow{4}{*}{$\begin{array}{l}1.2 \\
\text { Population } \\
\text { size }\end{array}$} & \multirow{4}{*}{ Population abundance and/or biomass (1.2.1) } & a. Mammals \\
\hline & & b. Fish \\
\hline & & c. Benthos \\
\hline & & d. Birds \\
\hline \multirow{5}{*}{$\begin{array}{l}1.3 \\
\text { Population } \\
\text { condition }\end{array}$} & \multirow{4}{*}{$\begin{array}{l}\text { Population demographic characteristics (e.g. body } \\
\text { size or age class structure, sex ratio, fecundity rates, } \\
\text { survival/mortality rates)(1.3.1) }\end{array}$} & a. Mammals \\
\hline & & b. Fish \\
\hline & & c. Benthos \\
\hline & & d. Birds \\
\hline & Population genetic structure (1.3.2) & Benthos \\
\hline \multirow{7}{*}{$\begin{array}{l}1.4 \\
\text { Habitat } \\
\text { distribution }\end{array}$} & \multirow[t]{4}{*}{ Habitat distributional range (1.4.1) } & a. Pelagic habitats \\
\hline & & b. Rock and biogenic reef habitats \\
\hline & & c. Sediment habitats \\
\hline & & d. Other habitats \\
\hline & \multirow[t]{3}{*}{ Habitat distributional pattern (1.4.2) } & a. Pelagic habitats \\
\hline & & b. Rock and biogenic reef habitats \\
\hline & & c. Sediment habitats \\
\hline \multirow{4}{*}{$\begin{array}{l}1.5 \\
\text { Habitat } \\
\text { extent }\end{array}$} & \multirow[t]{3}{*}{ Habitat area (1.5.1) } & a. Rock and biogenic reef habitats \\
\hline & & b. Sediment habitat \\
\hline & & c. Other habitats \\
\hline & Habitat volume where relevant (1.5.2) & \\
\hline \multirow{8}{*}{$\begin{array}{l}1.6 \\
\text { Habitat } \\
\text { condition }\end{array}$} & \multirow{4}{*}{$\begin{array}{l}\text { Condition of the typical species and communities } \\
(1.6 .1)\end{array}$} & a. Pelagic habitats \\
\hline & & b. Rock and biogenic reef habitats \\
\hline & & c. Sediment habitat \\
\hline & & d. Benthos \\
\hline & \multirow[t]{3}{*}{ Relative abundance and/or biomass (1.6.2) } & a. Pelagic habitats \\
\hline & & b. Rock and biogenic reef habitats \\
\hline & & c. Other Habitats \\
\hline & Physical, hydrological and chemical conditions (1.6.3) & Sediment habitat \\
\hline \multirow{3}{*}{$\begin{array}{l}1.7 \\
\text { Ecosystem } \\
\text { structure }\end{array}$} & \multirow{3}{*}{$\begin{array}{l}\text { Composition and relative proportions of ecosystem } \\
\text { components (habitats and species) (1.7.1) }\end{array}$} & a. Fish \\
\hline & & b. Pelagic habitats \\
\hline & & c. Foodweb \\
\hline
\end{tabular}


Table 2: Country scores for the ecological relevance and operability of Parameters for Descriptor D1 on Biological Diversity proposed by the different countries (group-codes are according Table 1).

References used are for Belgium: Belgische Staat 2012, État Belge 2012; Cyprus: DFMR 2012a,b,c, 2014a,b; Denmark: DME 2012, 2014;

Finland: SYKE 2012, 2014; France: Guérin et al 2013, Dupont et al 2014, SRMC 2014, SRMG 2014, SRMM 2014; Germany: BLMP 2014, BMUB 2014a,b,c; Greece: MEECC 2014, Italy: MATTM 2009, 2010, Munari \& Mistri 2010, COREM 2012, Cima \& Ballarin 2013, ISPRA 2013, Tunesi et al 2013, Milieu 2014a; Latvia: LHEI 2012, 2014, MARMONI 2014; Netherlands: MIE 2012, 2014; Norway: Certain et al 2011, Nybø et al 2011, 2012, Aslaksen \& Garnåsjordet 2012, Aslaksen et al 2012; Poland: Krzymiński 2013, 2014; Portugal: MAMAOT 2012, 2014; Russia: Guide to hydrological work in the oceans and seas 1977, Anonymous 1985, VNIRO 2004; Slovenia: Peterlin et al 2013; Spain: Anonymous 2010, Borja et al 2011, Arcos et al 2012, Gil et al 2012, Gil de Sola et al 2012, Hernández et al 2012, MAGRAMA 2014, Ruiz et al 2012, Santos Vázquez et al 2012, Velasco et al 2012, Milieu 2014b, Palialexis et al 2014; Turkey: UNEP/MAP 2007, MFWM 2008, Şekeroğlu et al 2011, Sumer \& Muluk 2011; Ukraine: Losovskaya 2005, Zamora et al 2005, Anistratenko et al 2007, Mikhalev 2008, Gladilina 2010, MENRU 2010, Petrenko 2013, Vishnyakova \& Gol'din 2014, United Kingdom: Cook et al 2012, ICES 2013, OSPAR Commission 2013, Burrows et al 2014a,b, DEFRA 2014, Fariñas-Franco et al 2014, Haynes et al 2014.

Legend to Table 2:

\begin{tabular}{|c|c|c|c|}
\hline Relevance of Parameter chosen by country & Operational status & Combined score & Color code for combined score \\
\hline \multicolumn{4}{|l|}{ 2: Parameter is definitely ecological relevant } \\
\hline \multicolumn{4}{|l|}{ 1: Parameter is somewhat ecological relevant } \\
\hline \multicolumn{4}{|l|}{ 0: No Parameter available or not relevant } \\
\hline & 2: Operational & & \\
\hline & 1: Under Development & & \\
\hline & 0: Not operational & & \\
\hline $\mathbf{0}$ & 0 & Sum count 0 & $0.0-0.8$ : Implementation of MSFD D1 is Poor \\
\hline $0 / 1$ & $1 / 0$ & Sum count 1 & $0.8-1.6:$ : Implementation of MSFD D1 is Inadequate \\
\hline 1 & 1 & Sum count 2 & $1.6-2.4:$ : Implementation of MSFD D1 is Moderate \\
\hline $1 / 2$ & $2 / 1$ & Sum count 3 & 2.4 - 3.2: : Implementation of MSFD D1 is Good \\
\hline 2 & 2 & Sum count 4 & 3.2-4.0: Implementation of MSFD D1 is Full \\
\hline
\end{tabular}


Hummel et al. 2015. Implementation of MSFD D1 Biodiversity in Europe

(Table 2 (continued)

\begin{tabular}{|c|c|c|c|c|c|c|c|c|c|c|c|c|c|c|c|}
\hline Group & Albania & Albania & Albania & Belgium & Belgium & Belgium & Cyprus & Cyprus & Cyprus & Denmark & Denmark & Denmark & Finland & Finland & Finland \\
\hline Code & $\begin{array}{c}\text { Relevanc } \\
\text { e }\end{array}$ & $\begin{array}{c}\text { Operation } \\
\text { al status }\end{array}$ & $\begin{array}{c}\text { Combine } \\
\text { d }\end{array}$ & Relevance & $\begin{array}{l}\text { Operation } \\
\text { al status }\end{array}$ & $\begin{array}{c}\text { Combine } \\
\text { d }\end{array}$ & $\begin{array}{c}\text { Relevanc } \\
\text { e }\end{array}$ & $\begin{array}{c}\text { Operation } \\
\text { al status }\end{array}$ & $\begin{array}{c}\text { Combine } \\
\text { d }\end{array}$ & Relevance & $\begin{array}{c}\text { Operation } \\
\text { al status }\end{array}$ & Combined & Relevance & $\begin{array}{l}\text { Operation } \\
\text { al status }\end{array}$ & Combined \\
\hline 1.1.1.a & 0 & 0 & 0 & 1 & 2 & 3 & 1 & 1 & 2 & 1 & 2 & 3 & 2 & 2 & 4 \\
\hline 1.1.1.b & 0 & 0 & 0 & 1 & 2 & 3 & 2 & 2 & 4 & 0 & 0 & 0 & 1 & 2 & 3 \\
\hline 1.1.1.c & 0 & 0 & 0 & 2 & 0 & 2 & 2 & 2 & 4 & 0 & 0 & 0 & 0 & 0 & 0 \\
\hline 1.1.1.d & 0 & 0 & 0 & 1 & 2 & 3 & 1 & 1 & 2 & 1 & 2 & 3 & 2 & 1 & 3 \\
\hline 1.1.2.a & 0 & 0 & 0 & 1 & 0 & 1 & 1 & 1 & 2 & 1 & 2 & 3 & 2 & 2 & 4 \\
\hline 1.1.2.b & 0 & 0 & 0 & 1 & 0 & 1 & 2 & 2 & 4 & 0 & 0 & 0 & 0 & 0 & 0 \\
\hline 1.1.2.c & 0 & 0 & 0 & 2 & 0 & 2 & 1 & 2 & 3 & 0 & 0 & 0 & 0 & 0 & 0 \\
\hline 1.1.2.d & 0 & 0 & 0 & 1 & 0 & 1 & 1 & 1 & 2 & 1 & 2 & 3 & 2 & 1 & 3 \\
\hline 1.1 .3 & 0 & 0 & 0 & 2 & 1 & 3 & 1 & 2 & 3 & 2 & 0 & 2 & 1 & 1 & 2 \\
\hline 1.2.1.a & 0 & 0 & 0 & 1 & 2 & 3 & 1 & 1 & 2 & 1 & 2 & 3 & 0 & 0 & 0 \\
\hline 1.2.1.b & 0 & 0 & 0 & 1 & 2 & 3 & 2 & 2 & 4 & 0 & 0 & 0 & 2 & 1 & 3 \\
\hline 1.2.1.c & 0 & 0 & 0 & 2 & 1 & 3 & 1 & 2 & 3 & 0 & 0 & 0 & 0 & 0 & 0 \\
\hline 1.2.1.d & 0 & 0 & 0 & 1 & 2 & 3 & 1 & 1 & 2 & 1 & 1 & 2 & 2 & 1 & 3 \\
\hline 1.3.1.a & 0 & 0 & 0 & 1 & 2 & 3 & 1 & 1 & 2 & 1 & 2 & 3 & 2 & 2 & 4 \\
\hline 1.3.1.b & 0 & 0 & 0 & 1 & 2 & 3 & 2 & 2 & 4 & 0 & 0 & 0 & 2 & 2 & 4 \\
\hline 1.3.1.c & 0 & 0 & 0 & 2 & 0 & 2 & 0 & 0 & 0 & 0 & 0 & 0 & 2 & 2 & 4 \\
\hline 1.3.1.d & 0 & 0 & 0 & 1 & 1 & 2 & 1 & 1 & 2 & 2 & 2 & 4 & 2 & 2 & 4 \\
\hline 1.3 .2 & 0 & 0 & 0 & 0 & 0 & 0 & 0 & 0 & 0 & 0 & 0 & 0 & 0 & 0 & 0 \\
\hline 1.4.1.a & 0 & 0 & 0 & 1 & 0 & 1 & 1 & 0 & 1 & 0 & 0 & 0 & 2 & 1 & 3 \\
\hline 1.4.1.b & 0 & 0 & 0 & 1 & 0 & 1 & 1 & 0 & 1 & 2 & 1 & 3 & 2 & 1 & 3 \\
\hline 1.4.1.c & 0 & 0 & 0 & 2 & 1 & 3 & 1 & 0 & 1 & 1 & 1 & 2 & 2 & 1 & 3 \\
\hline 1.4.1.d & 0 & 0 & 0 & 1 & 1 & 2 & 1 & 1 & 2 & 1 & 1 & 2 & 2 & 1 & 3 \\
\hline 1.4.2.a & 0 & 0 & 0 & 0 & 0 & 0 & 0 & 0 & 0 & 0 & 0 & 0 & 0 & 0 & 0 \\
\hline 1.4.2.b & 0 & 0 & 0 & 1 & 1 & 2 & 0 & 0 & 0 & 1 & 1 & 2 & 0 & 0 & 0 \\
\hline 1.4.2.c & 0 & 0 & 0 & 2 & 1 & 3 & 0 & 0 & 0 & 1 & 1 & 2 & 0 & 0 & 0 \\
\hline 1.5.1.a & 0 & 0 & 0 & 2 & 0 & 2 & 0 & 0 & 0 & 2 & 1 & 3 & 2 & 1 & 3 \\
\hline 1.5.1.b & 0 & 0 & 0 & 1 & 0 & 1 & 0 & 0 & 0 & 1 & 1 & 2 & 2 & 1 & 3 \\
\hline 1.5.1.c & 0 & 0 & 0 & 1 & 0 & 1 & 1 & 1 & 2 & 1 & 1 & 2 & 2 & 1 & 3 \\
\hline 1.5 .2 & 0 & 0 & 0 & 0 & 0 & 0 & 0 & 0 & 0 & 1 & 1 & 2 & 2 & 1 & 3 \\
\hline 1.6.1.a & 0 & 0 & 0 & 1 & 0 & 1 & 0 & 0 & 0 & 0 & 0 & 0 & 2 & 1 & 3 \\
\hline 1.6.1.b & 0 & 0 & 0 & 0 & 0 & 0 & 1 & 2 & 3 & 1 & 2 & 3 & 2 & 1 & 3 \\
\hline 1.6.1.c & 0 & 0 & 0 & 2 & 2 & 4 & 1 & 2 & 3 & 1 & 2 & 3 & 2 & 1 & 3 \\
\hline 1.6.1.d & 0 & 0 & 0 & 1 & 1 & 2 & 2 & 2 & 4 & 1 & 2 & 3 & 2 & 1 & 3 \\
\hline 1.6.2.a & 0 & 0 & 0 & 1 & 0 & 1 & 1 & 0 & 1 & 0 & 0 & 0 & 0 & 0 & 0 \\
\hline 1.6.2.b & 0 & 0 & 0 & 2 & 0 & 2 & 1 & 2 & 3 & 2 & 1 & 3 & 0 & 0 & 0 \\
\hline 1.6.2.c & 0 & 0 & 0 & 2 & 0 & 2 & 1 & 2 & 3 & 1 & 2 & 3 & 1 & 1 & 2 \\
\hline 1.6 .3 & 0 & 0 & 0 & 2 & 0 & 2 & 1 & 1 & 2 & 2 & 2 & 4 & 2 & 2 & 4 \\
\hline 1.7.1.a & 0 & 0 & 0 & 2 & 0 & 2 & 1 & 1 & 2 & 1 & 1 & 2 & 2 & 1 & 3 \\
\hline 1.7.1.b & 0 & 0 & 0 & 1 & 0 & 1 & 0 & 0 & 0 & 1 & 1 & 2 & 2 & 1 & 3 \\
\hline 1.7.1.c & 0 & 0 & 0 & 1 & 0 & 1 & 0 & 0 & 0 & 1 & 1 & 2 & 2 & 1 & 3 \\
\hline \multicolumn{2}{|c|}{ Average score } & & 0 & & & 1,875 & & & 1,825 & & & 1,775 & & & 2,3 \\
\hline
\end{tabular}


Hummel et al. 2015. Implementation of MSFD D1 Biodiversity in Europe

(Table 2 continued)

\begin{tabular}{|c|c|c|c|c|c|c|c|c|c|c|c|c|c|c|c|}
\hline Group & France & France & France & Germany & Germany & Germany & Greece & Greece & Greece & Italy & Italy & Italy & \begin{tabular}{|l|} 
Latvia \\
\end{tabular} & Latvia & \begin{tabular}{|l} 
Latvia \\
\end{tabular} \\
\hline Code & $\begin{array}{c}\text { Relevanc } \\
\text { e }\end{array}$ & $\begin{array}{l}\text { Operation } \\
\text { al status }\end{array}$ & $\begin{array}{c}\text { Combine } \\
\text { d }\end{array}$ & Relevance & \begin{tabular}{|c|} 
Operation \\
al status
\end{tabular} & $\begin{array}{c}\text { Combine } \\
\text { d }\end{array}$ & Relevance & $\begin{array}{c}\text { Operation } \\
\text { al status }\end{array}$ & Combined & Relevance & $\begin{array}{c}\text { Operation } \\
\text { al status }\end{array}$ & Combined & Relevance & $\begin{array}{c}\text { Operation } \\
\text { al status }\end{array}$ & Combined \\
\hline 1.1.1.a & 1 & 2 & 3 & 2 & 2 & 4 & 1 & 1 & 2 & 0 & 0 & 0 & 0 & 0 & 0 \\
\hline 1.1.1.b & 2 & 1 & 3 & 2 & 2 & 4 & 2 & 2 & 4 & 0 & 0 & 0 & 2 & 2 & 4 \\
\hline 1.1.1.c & 0 & 0 & 0 & 2 & 1 & 3 & 1 & 2 & 3 & 0 & 0 & 0 & 2 & 2 & 4 \\
\hline 1.1.1.d & 2 & 2 & 4 & 2 & 2 & 4 & 0 & 2 & 2 & 0 & 0 & 0 & 2 & 1 & 3 \\
\hline 1.1.2.a & 1 & 2 & 3 & 2 & 2 & 4 & 1 & 1 & 2 & 0 & 0 & 0 & 0 & 0 & 0 \\
\hline 1.1.2.b & 2 & 1 & 3 & 2 & 2 & 4 & 2 & 2 & 4 & 0 & 0 & 0 & 0 & 0 & 0 \\
\hline 1.1.2.c & 0 & 0 & 0 & 2 & 1 & 3 & 0 & 1 & 1 & 0 & 0 & 0 & 0 & 0 & 0 \\
\hline 1.1.2.d & 2 & 2 & 4 & 2 & 2 & 4 & 0 & 2 & 2 & 0 & 0 & 0 & 2 & 1 & 3 \\
\hline 1.1 .3 & 0 & 0 & 0 & 2 & 1 & 3 & 2 & 2 & 4 & 0 & 0 & 0 & 0 & 0 & 0 \\
\hline 1.2.1.a & 2 & 2 & 4 & 2 & $\overline{2}$ & $\overline{4}$ & 1 & 1 & 2 & $\overline{1}$ & 2 & 3 & 0 & 0 & 0 \\
\hline 1.2.1.b & 2 & 1 & 3 & 1 & 1 & 2 & 2 & 2 & 4 & 1 & 2 & 3 & 2 & 1 & 3 \\
\hline 1.2.1.c & 0 & 0 & 0 & 2 & 2 & 4 & 2 & 1 & 3 & 1 & 2 & 3 & 0 & 0 & 0 \\
\hline $1.2 .1 . \mathrm{d}$ & 2 & 2 & 4 & 2 & 2 & 4 & 1 & 1 & 2 & 1 & 1 & 2 & 2 & 2 & 4 \\
\hline 1.3.1.a & 1 & 2 & 3 & 2 & 2 & 4 & 1 & 1 & 2 & 0 & 0 & 0 & 0 & 0 & 0 \\
\hline 1.3.1.b & 2 & 1 & 3 & 1 & 1 & 2 & 1 & 2 & 3 & 1 & 2 & 3 & 0 & 0 & 0 \\
\hline 1.3.1.c & 0 & 0 & 0 & 2 & 1 & 3 & 0 & 0 & 0 & 1 & 2 & 3 & 2 & 2 & 4 \\
\hline 1.3.1.d & 2 & 2 & 4 & 2 & 2 & 4 & 1 & 1 & 2 & 1 & 1 & 2 & 2 & 1 & 3 \\
\hline 1.3 .2 & 1 & 0 & 1 & 0 & 0 & 0 & 0 & 1 & 1 & 1 & 1 & 2 & 0 & 0 & 0 \\
\hline 1.4.1.a & 2 & $\overline{1}$ & 3 & 0 & 0 & 0 & 2 & 2 & 4 & 0 & 0 & 0 & 0 & 0 & 0 \\
\hline 1.4.1.b & 2 & 1 & 3 & 2 & 1 & 3 & 1 & 1 & 2 & 0 & 0 & 0 & 2 & 2 & 4 \\
\hline 1.4.1.c & 2 & 1 & 3 & 2 & 1 & 3 & 1 & 1 & 2 & 0 & 0 & 0 & 0 & 0 & 0 \\
\hline 1.4.1.d & 1 & 0 & 1 & 0 & 0 & 0 & 2 & 2 & 4 & 0 & 0 & 0 & 0 & 0 & 0 \\
\hline 1.4.2.a & 2 & 1 & 3 & 1 & 1 & 2 & 1 & 1 & 2 & 0 & 0 & 0 & 0 & 0 & 0 \\
\hline 1.4.2.b & 2 & 1 & 3 & 2 & 1 & 3 & 1 & 1 & 2 & 0 & 0 & 0 & 0 & 0 & 0 \\
\hline 1.4.2.c & 2 & 1 & 3 & 2 & 1 & 3 & 1 & 1 & 2 & 0 & 0 & 0 & 0 & 0 & 0 \\
\hline 1.5.1.a & 2 & 1 & 3 & 2 & 1 & 3 & 2 & 1 & 3 & $\overline{1}$ & 2 & 3 & 2 & $\overline{1}$ & 3 \\
\hline 1.5.1.b & 2 & 1 & 3 & 2 & 1 & 3 & 2 & 1 & 3 & 0 & 0 & 0 & 0 & 0 & 0 \\
\hline 1.5.1.c & 1 & 0 & 1 & 0 & 0 & 0 & 2 & 2 & 4 & 1 & 2 & 3 & 0 & 0 & 0 \\
\hline 1.5 .2 & 1 & 1 & 2 & 0 & 0 & 0 & 1 & 0 & 1 & 0 & 0 & 0 & 0 & 0 & 0 \\
\hline 1.6.1.a & $\overline{2}$ & 1 & 3 & 1 & 1 & 2 & 1 & 1 & 2 & 0 & 0 & 0 & 2 & 1 & 3 \\
\hline 1.6.1.b & 2 & 1 & 3 & 0 & 0 & 0 & 1 & 1 & 2 & 1 & 2 & 3 & 2 & 2 & 4 \\
\hline 1.6.1.c & 2 & 1 & 3 & 0 & 0 & 0 & 2 & 2 & 4 & 0 & 0 & 0 & 2 & 2 & 4 \\
\hline 1.6.1.d & 1 & 0 & 1 & 2 & 1 & 3 & 2 & 2 & 4 & 1 & 2 & 3 & 2 & 2 & 4 \\
\hline 1.6.2.a & 2 & 1 & 3 & 1 & 1 & 2 & 1 & 1 & 2 & 1 & 2 & 3 & 2 & 1 & 3 \\
\hline 1.6.2.b & 2 & 1 & 3 & 2 & 1 & 3 & 1 & 1 & 2 & 0 & 0 & 0 & 2 & 2 & 4 \\
\hline 1.6.2.c & 1 & 0 & 1 & 2 & 1 & 3 & 1 & 1 & 2 & 1 & 2 & 3 & 1 & 1 & 2 \\
\hline 1.6 .3 & 2 & 1 & 3 & 1 & 1 & 2 & 2 & 1 & 3 & 0 & 0 & 0 & 1 & 1 & 2 \\
\hline 1.7.1.a & 2 & 1 & 3 & 2 & 1 & 3 & 1 & 2 & 3 & $\overline{1}$ & $\overline{1}$ & 2 & 2 & 2 & 4 \\
\hline 1.7.1.b & 2 & 1 & 3 & 1 & 1 & 2 & 1 & 1 & 2 & 1 & 1 & 2 & 2 & 1 & 3 \\
\hline 1.7.1.c & 2 & 1 & 3 & 2 & 1 & 3 & 0 & 0 & 0 & 1 & 1 & 2 & 0 & 0 & 0 \\
\hline \multicolumn{3}{|c|}{ Average score } & 2,475 & & & 2,575 & & & 2,45 & & & 1,125 & & & 1,7 \\
\hline
\end{tabular}


Hummel et al. 2015. Implementation of MSFD D1 Biodiversity in Europe

(Table 2 continued)

\begin{tabular}{|c|c|c|c|c|c|c|c|c|c|c|c|c|c|c|c|}
\hline Group & $\begin{array}{c}\text { Nether } \\
\text { lands }\end{array}$ & $\begin{array}{c}\text { Nether } \\
\text { lands }\end{array}$ & $\begin{array}{c}\text { Nether } \\
\text { lands }\end{array}$ & Norway & Norway & Norway & Poland & Poland & Poland & Portugal & Portugal & Portugal & Russia & Russia & Russia \\
\hline Code & Relevance & $\begin{array}{l}\text { Operation } \\
\text { al status }\end{array}$ & $\begin{array}{c}\text { Combine } \\
\text { d }\end{array}$ & $\begin{array}{c}\text { Relevanc } \\
\text { e }\end{array}$ & $\begin{array}{l}\text { Operation } \\
\text { al status }\end{array}$ & $\begin{array}{c}\text { Combine } \\
d\end{array}$ & Relevance & $\begin{array}{l}\text { Operation } \\
\text { al status }\end{array}$ & Combined & Relevance & $\begin{array}{c}\text { Operation } \\
\text { al status }\end{array}$ & Combined & Relevance & $\begin{array}{c}\text { Operation } \\
\text { al status }\end{array}$ & Combined \\
\hline 1.1.1.a & 1 & 2 & 3 & 2 & 2 & 4 & 0 & 0 & 0 & 0 & 0 & 0 & 1 & 1 & 2 \\
\hline 1.1.1.b & 2 & 1 & 3 & 2 & 2 & 4 & 1 & 0 & 1 & 0 & 0 & 0 & 2 & 2 & 4 \\
\hline 1.1.1.c & 2 & 1 & 3 & 2 & 2 & 4 & 1 & 0 & 1 & 0 & 0 & 0 & 2 & 2 & 4 \\
\hline 1.1.1.d & 1 & 2 & 3 & 2 & 2 & 4 & 0 & 0 & 0 & 0 & 0 & 0 & 0 & 0 & 0 \\
\hline 1.1.2.a & 1 & 2 & 3 & 2 & 2 & 4 & 0 & 0 & 0 & 0 & 0 & 0 & 1 & 1 & 2 \\
\hline 1.1.2.b & 2 & 1 & 3 & 2 & 2 & 4 & 1 & 0 & 1 & 2 & 1 & 3 & 1 & 1 & 2 \\
\hline $1.1 .2 . \mathrm{c}$ & 2 & 1 & 3 & 2 & 2 & 4 & 1 & 0 & 1 & 2 & 1 & 3 & 2 & 2 & 4 \\
\hline $1.1 .2 . \mathrm{d}$ & 1 & 2 & 3 & 2 & 2 & 4 & 0 & 0 & 0 & 2 & 1 & 3 & 0 & 0 & 0 \\
\hline 1.1 .3 & 2 & 2 & 4 & 1 & 1 & 2 & 0 & 0 & 0 & 0 & 0 & 0 & 2 & 1 & 3 \\
\hline 1.2.1.a & 1 & 2 & 3 & 2 & 2 & 4 & 2 & 2 & 4 & 0 & 0 & 0 & 0 & 0 & 0 \\
\hline 1.2.1.b & 2 & 1 & 3 & 2 & 2 & 4 & 2 & 1 & 3 & 2 & 1 & 3 & 1 & 2 & 3 \\
\hline 1.2.1.c & 2 & 2 & 4 & 2 & 2 & 4 & 1 & 0 & 1 & 2 & 1 & 3 & 2 & 2 & 4 \\
\hline $1.2 .1 . \mathrm{d}$ & 1 & 2 & 3 & 2 & 2 & 4 & 0 & 0 & 0 & 2 & 1 & 3 & 0 & 0 & 0 \\
\hline 1.3.1.a & 0 & 2 & 2 & 1 & 1 & 2 & 2 & 2 & 4 & 0 & 0 & 0 & 0 & 0 & 0 \\
\hline 1.3.1.b & 1 & 1 & 2 & 1 & 1 & 2 & 2 & 2 & 4 & 0 & 0 & 0 & 0 & 0 & 0 \\
\hline 1.3.1.c & 1 & 2 & 3 & 1 & 1 & 2 & 2 & 1 & 3 & 0 & 0 & 0 & 1 & 0 & 1 \\
\hline 1.3.1.d & 1 & 2 & 3 & 1 & 1 & 2 & 2 & 2 & 4 & 0 & 0 & 0 & 0 & 0 & 0 \\
\hline 1.3 .2 & 0 & 0 & 0 & 1 & 1 & 2 & 1 & 0 & 1 & 1 & 0 & 1 & 2 & 0 & 2 \\
\hline 1.4.1.a & 0 & 0 & 0 & 2 & 2 & 4 & 0 & 0 & 0 & 2 & 1 & 3 & 0 & 0 & 0 \\
\hline 1.4.1.b & 0 & 0 & 0 & 2 & 2 & 4 & 0 & 0 & 0 & 2 & 1 & 3 & 0 & 0 & 0 \\
\hline 1.4.1.c & 0 & 0 & 0 & 2 & 2 & 4 & 0 & 0 & 0 & 2 & 1 & 3 & 1 & 0 & 1 \\
\hline 1.4.1.d & 1 & 2 & 3 & 1 & 1 & 2 & 0 & 0 & 0 & 2 & 1 & 3 & 0 & 0 & 0 \\
\hline 1.4.2.a & 0 & 0 & 0 & 0 & 0 & 0 & 0 & 0 & 0 & 2 & 1 & 3 & 0 & 0 & 0 \\
\hline 1.4.2.b & 0 & 0 & 0 & 0 & 0 & 0 & 0 & 0 & 0 & 2 & 1 & 3 & 0 & 0 & 0 \\
\hline 1.4.2.c & 0 & 0 & 0 & 0 & 0 & 0 & 0 & 0 & 0 & 2 & 1 & 3 & 0 & 0 & 0 \\
\hline 1.5.1.a & 0 & 0 & 0 & 2 & 2 & 4 & $\overline{1}$ & 2 & 3 & 2 & 1 & 3 & 0 & 0 & 0 \\
\hline 1.5.1.b & 0 & 0 & 0 & 2 & 2 & 4 & 1 & 2 & 3 & 2 & 1 & 3 & 1 & 0 & 1 \\
\hline 1.5.1.c & 1 & 2 & 3 & 1 & 1 & 2 & 1 & 2 & 3 & 2 & 1 & 3 & 0 & 0 & 0 \\
\hline 1.5 .2 & 0 & 0 & 0 & 0 & 0 & 0 & 1 & 2 & 3 & 0 & 0 & 0 & 0 & 0 & 0 \\
\hline 1.6.1.a & 0 & 0 & 0 & 2 & 2 & 4 & 2 & 2 & 4 & 2 & 1 & 3 & 1 & 0 & 1 \\
\hline 1.6.1.b & 0 & 0 & 0 & 2 & 2 & 4 & 0 & 0 & 0 & 2 & 1 & 3 & 0 & 1 & 1 \\
\hline 1.6.1.c & 0 & 0 & 0 & 2 & 2 & 4 & 2 & 2 & 4 & 2 & 1 & 3 & 1 & 2 & 3 \\
\hline 1.6.1.d & 2 & 2 & 4 & 2 & 2 & 4 & 2 & 2 & 4 & 2 & 1 & 3 & 1 & 2 & 3 \\
\hline 1.6.2.a & 0 & 0 & 0 & 2 & 2 & 4 & 2 & 2 & 4 & 2 & 1 & 3 & 1 & 2 & 3 \\
\hline $1.6 .2 . \mathrm{b}$ & 0 & 0 & 0 & 2 & 2 & 4 & 0 & 0 & 0 & 2 & 1 & 3 & 0 & 1 & 1 \\
\hline 1.6.2.c & 2 & 2 & 4 & 0 & 0 & 0 & 2 & 2 & 4 & 2 & 1 & 3 & 0 & 1 & 1 \\
\hline 1.6 .3 & 2 & 1 & 3 & 0 & 0 & 0 & 2 & 2 & 4 & 0 & 0 & 0 & 2 & 2 & 4 \\
\hline 1.7.1.a & 0 & 1 & $\overline{1}$ & $\overline{1}$ & $\overline{1}$ & 2 & 2 & 2 & 4 & 0 & $\overline{0}$ & 0 & 1 & 0 & 1 \\
\hline 1.7.1.b & 0 & 1 & 1 & 1 & 1 & 2 & 1 & 0 & 1 & 0 & 0 & 0 & 0 & 1 & 1 \\
\hline 1.7.1.c & $\begin{array}{l}1 \\
\end{array}$ & 2 & 3 & 0 & 0 & 0 & 0 & 0 & 0 & 0 & 0 & 0 & 1 & 0 & 1 \\
\hline \multicolumn{3}{|c|}{ Average score } & 1,825 & & & 2,8 & & & 1,725 & & & 1,75 & & & 1,325 \\
\hline
\end{tabular}


Hummel et al. 2015. Implementation of MSFD D1 Biodiversity in Europe

(Table 2 continued)

\begin{tabular}{|c|c|c|c|c|c|c|c|c|c|c|c|c|c|c|c|}
\hline Group & Slovenia & Slovenia & Slovenia & Spain & Spain & Spain & Turkey & Turkey & Turkey & UK & UK & UK & Ukraine & Ukraine & Ukraine \\
\hline Code & Relevance & $\begin{array}{l}\text { Operation } \\
\text { al status }\end{array}$ & $\begin{array}{c}\text { Combine } \\
\text { d }\end{array}$ & Relevance & $\begin{array}{c}\text { Operation } \\
\text { al status }\end{array}$ & $\begin{array}{c}\text { Combine } \\
\text { d }\end{array}$ & Relevance & $\begin{array}{l}\text { Operation } \\
\text { al status }\end{array}$ & Combined & $\begin{array}{c}\text { Relevanc } \\
\text { e }\end{array}$ & $\begin{array}{c}\text { Operation } \\
\text { al status }\end{array}$ & $\begin{array}{c}\text { Combine } \\
\text { d }\end{array}$ & $\begin{array}{c}\text { Relevanc } \\
\text { e }\end{array}$ & $\begin{array}{l}\text { Operation } \\
\text { al status }\end{array}$ & $\begin{array}{c}\text { Combine } \\
\text { d }\end{array}$ \\
\hline 1.1.1.a & 2 & 2 & 4 & 2 & 1 & 3 & 2 & 1 & 3 & 1 & 2 & 3 & 1 & 2 & 3 \\
\hline 1.1.1.b & 0 & 0 & 0 & 2 & 2 & 4 & 2 & 1 & 3 & 2 & 2 & 4 & 2 & 0 & 2 \\
\hline 1.1.1.c & 0 & 0 & 0 & 2 & 0 & 2 & 2 & 1 & 3 & 0 & 0 & 0 & 0 & 0 & 0 \\
\hline 1.1.1.d & 2 & 2 & 4 & 1 & 2 & 3 & 2 & 1 & 3 & 0 & 0 & 0 & 1 & 2 & 3 \\
\hline 1.1.2.a & 0 & 0 & 0 & 1 & 1 & 2 & 2 & 1 & 3 & 1 & 2 & 3 & 2 & 0 & 2 \\
\hline 1.1.2.b & 0 & 0 & 0 & 1 & 2 & 3 & 2 & 1 & 3 & 2 & 2 & 4 & 1 & 0 & 1 \\
\hline 1.1.2.c & 0 & 0 & 0 & 1 & 0 & 1 & 2 & 1 & 3 & 0 & 0 & 0 & 0 & 0 & 0 \\
\hline 1.1.2.d & 0 & 0 & 0 & 1 & 2 & 3 & 2 & 1 & 3 & 1 & 2 & 3 & 0 & 0 & 0 \\
\hline 1.1 .3 & 2 & 1 & 3 & 2 & 0 & 2 & 2 & 1 & 3 & 0 & 0 & 0 & 0 & 0 & 0 \\
\hline 1.2.1.a & 2 & 2 & 4 & 1 & 2 & 3 & 2 & 1 & 3 & 1 & 2 & 3 & 2 & 2 & 4 \\
\hline 1.2.1.b & 0 & 0 & 0 & 2 & 2 & 4 & 2 & 1 & 3 & 2 & 2 & 4 & 2 & 0 & 2 \\
\hline 1.2.1.c & 0 & 0 & 0 & 2 & 0 & 2 & 2 & 1 & 3 & 0 & 0 & 0 & 2 & 1 & 3 \\
\hline 1.2.1.d & 2 & 2 & 4 & 1 & 2 & 3 & 2 & 1 & 3 & 1 & 2 & 3 & 2 & 0 & 2 \\
\hline 1.3.1.a & 0 & 0 & 0 & 1 & 2 & 3 & 2 & 1 & 3 & 1 & 2 & 3 & 2 & 2 & 4 \\
\hline 1.3.1.b & 0 & 0 & 0 & 2 & 2 & 4 & 2 & 1 & 3 & 1 & 2 & 3 & 2 & 2 & 4 \\
\hline 1.3.1.c & 0 & 0 & 0 & 1 & 0 & 1 & 2 & 0 & 2 & 0 & 0 & 0 & 2 & 1 & 3 \\
\hline $1.3 .1 . \mathrm{d}$ & 0 & 0 & 0 & 0 & 2 & 2 & 2 & 1 & 3 & 1 & 2 & 3 & 2 & 1 & 3 \\
\hline 1.3 .2 & 0 & 0 & 0 & 0 & 0 & 0 & 2 & 0 & 2 & 0 & 0 & 0 & 0 & 0 & 0 \\
\hline 1.4.1.a & 2 & 1 & 3 & 1 & 1 & 2 & 2 & 1 & 3 & 2 & 2 & 4 & 0 & 0 & 0 \\
\hline 1.4.1.b & 2 & 1 & 3 & 2 & 2 & 4 & 2 & 1 & 3 & 1 & 1 & 2 & 0 & 0 & 0 \\
\hline 1.4.1.c & 2 & 1 & 3 & 2 & 2 & 4 & 2 & 1 & 3 & 1 & 1 & 2 & 0 & 0 & 0 \\
\hline $1.4 .1 . \mathrm{d}$ & 0 & 0 & 0 & 0 & 0 & 0 & 2 & 1 & 3 & 0 & 0 & 0 & 0 & 0 & 0 \\
\hline 1.4.2.a & 0 & 0 & 0 & 1 & 1 & 2 & 2 & 1 & 3 & 2 & 2 & 4 & 0 & 0 & 0 \\
\hline 1.4.2.b & 0 & 0 & 0 & 1 & 0 & 1 & 2 & 1 & 3 & 1 & 1 & 2 & 0 & 0 & 0 \\
\hline 1.4.2.c & 0 & 0 & 0 & 1 & 0 & 1 & 2 & 1 & 3 & 1 & 1 & 2 & 0 & 0 & 0 \\
\hline 1.5.1.a & 2 & 1 & 3 & 1 & 2 & 3 & 2 & 1 & 3 & 1 & 1 & 2 & 0 & 0 & 0 \\
\hline 1.5.1.b & 2 & 1 & 3 & 1 & 2 & 3 & 2 & 1 & 3 & 1 & 1 & 2 & 0 & 0 & 0 \\
\hline $1.5 .1 . \mathrm{c}$ & 2 & 1 & 3 & 0 & 0 & 0 & 2 & 0 & 2 & 0 & 0 & 0 & 0 & 0 & 0 \\
\hline 1.5 .2 & 0 & 0 & 0 & 0 & 0 & 0 & 2 & 0 & 2 & 0 & 0 & 0 & 0 & 0 & 0 \\
\hline 1.6.1.a & 2 & 1 & 3 & 2 & 1 & 3 & 2 & 1 & 3 & 2 & 2 & 4 & 0 & 0 & 0 \\
\hline 1.6.1.b & 2 & 1 & 3 & 2 & 2 & 4 & 2 & 1 & 3 & 2 & 2 & 4 & 0 & 0 & 0 \\
\hline 1.6.1.c & 2 & 1 & 3 & 2 & 2 & 4 & 2 & 1 & 3 & 2 & 2 & 4 & 0 & 0 & 0 \\
\hline $1.6 .1 . \mathrm{d}$ & 2 & 1 & 3 & 2 & 2 & 4 & 2 & 1 & 3 & 0 & 0 & 0 & 0 & 0 & 0 \\
\hline 1.6.2.a & 0 & 0 & 0 & 2 & 0 & 2 & 2 & 1 & 3 & 1 & 2 & 3 & 0 & 0 & 0 \\
\hline 1.6.2.b & 0 & 0 & 0 & 2 & 2 & 4 & 2 & 1 & 3 & 1 & 1 & 2 & 0 & 0 & 0 \\
\hline 1.6.2.c & 0 & 0 & 0 & 1 & 0 & 1 & 2 & 1 & 3 & 0 & 0 & 0 & 0 & 0 & 0 \\
\hline 1.6 .3 & 0 & 0 & 0 & 1 & 1 & 2 & 2 & 2 & 4 & 2 & 1 & 3 & 2 & 2 & 4 \\
\hline 1.7.1.a & 0 & 0 & 0 & 1 & 2 & 3 & 2 & 1 & 3 & 1 & 2 & 3 & 2 & 1 & 3 \\
\hline 1.7.1.b & 0 & 0 & 0 & 1 & 1 & 2 & 2 & 1 & 3 & 2 & 2 & 4 & 2 & 1 & 3 \\
\hline 1.7.1.c & 0 & 0 & 0 & 2 & 1 & 3 & 2 & 0 & 2 & 0 & 0 & 0 & 2 & 1 & 3 \\
\hline \multicolumn{3}{|c|}{ Average scores } & 1,225 & & & 2,425 & & & 2,9 & & & 2,075 & & & 1,225 \\
\hline
\end{tabular}


Figure 1. Average score on relevance and operability of Parameters for Descriptor D1 on Biological Diversity proposed by the different European countries. Color codes mean that the MSFD D1 has been implemented: poorly (red), inadequately (orange), moderately (yellow), good (light green) and fully (dark green) (see for color codes also the legend in Table 2; data were checked for blank countries; not any country falls in the 'fully implemented' category) 
Hummel et al. 2015. Implementation of MSFD D1 Biodiversity in Europe

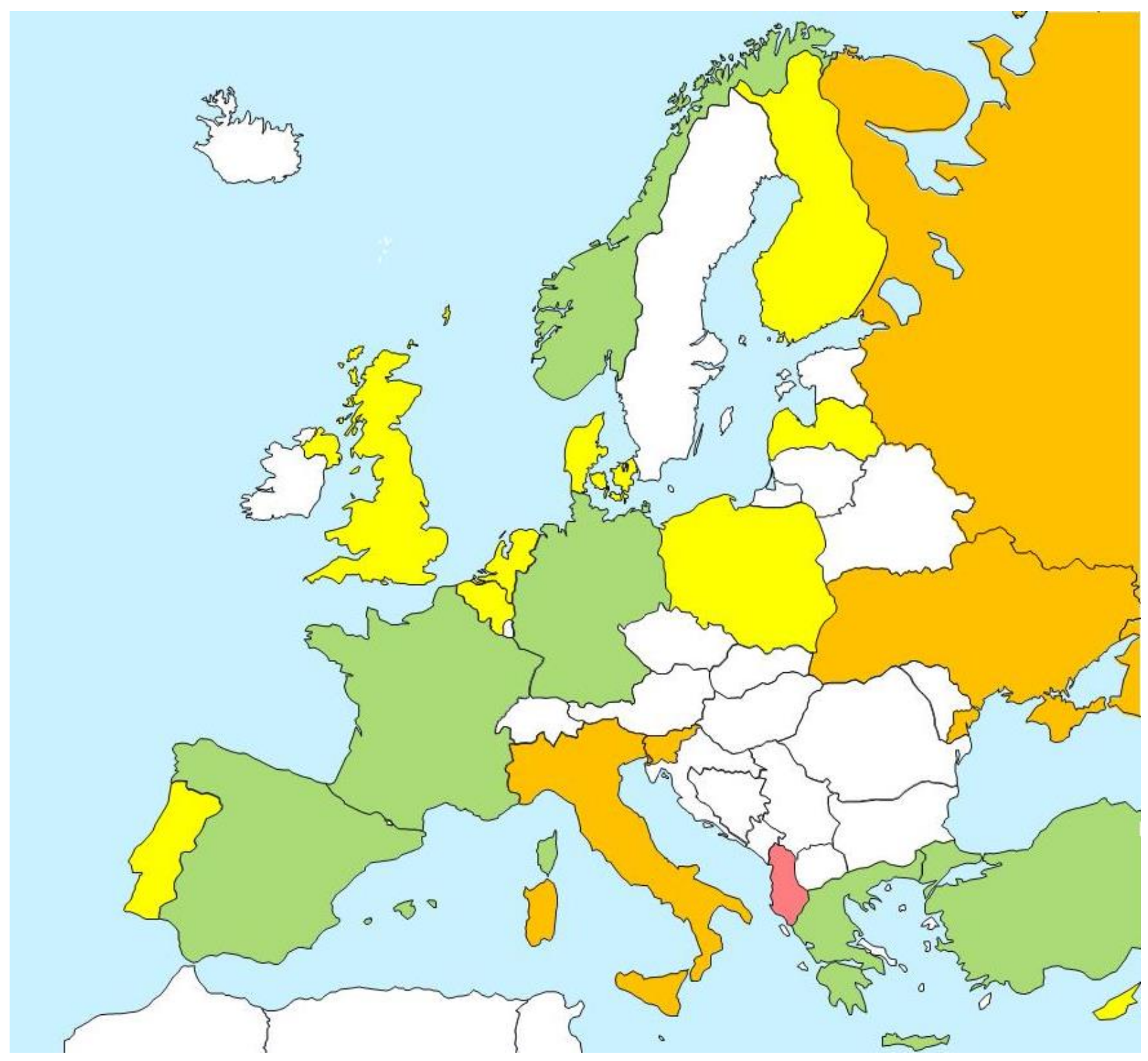

